\title{
Circadian gene variants and MT6s level in nurses under different work shifts - preliminary results
}

\author{
Edyta Reszka ${ }^{1 *}$, Beata Peplonska², Edyta Wieczorek', Jolanta Gromadzinska', Wojciech Sobala², \\ Wojciech Wasowicz' ${ }^{1}$ Agnieszka Bukowska², Jenny A Lie ${ }^{3}$ \\ From 16th International Charles Heidelberger Symposium on Cancer Research \\ Coimbra, Portugal. 26-28 September 2010
}

Epidemiological studies have found that long-term night-working women have a higher risk of breast cancer risk than women who do not work at night. According to circadian rhythm disruption hypothesis the underlying mechanism involves suppression of melatonin production caused by exposure to light at night. Circadian genes are responsible for adaptation of circadian rhythm and may influence cancer-related pathways. CYP1A2 is involved in melatonin metabolism.

The cross-sectional study of 360 nurses currently working on rotating night-shifts and 365 nurses who work only during the day was carried out in Lodz, Poland. Information on occupational history and breast cancer risk factors was collected during in-person interviews. Morning and evening urinary 6-sulfatoxymelatonin (MT6s) level and selected genetic polymorphism of CYP1A2 and some clock genes were analysed using RTPCR assays.

Preliminary analyses showed no significant associations between current rotating night shift work and morning or evening MT6 level. All SNPs were in Hardy-Weinberg Equilibrium, except Bmal1. There were no significant differences in the SNPs frequencies of CYP1A2, Bmal1, Clock, Cry1, Cry2, Per1, Per2, Per3 between nurses working rotating night shifts and these working day shifts only, irrespective of night shift duration. Adjusted linear regression analyses showed no significant associations between morning or evening MT6s and all analyzed SNPs except for Per2 (rs2304622); CC genotype was associated with higher level of evening urinary MT6s when compared to the GG (16.33 vs. 9.17 ng/g creatinine; $\mathrm{p}<0.01$ ).

\footnotetext{
* Correspondence: edyta@imp.lodz.pl

${ }^{1}$ Department of Toxicology, Nofer Institute of Occupational Medicine, Lodz, Poland

Full list of author information is available at the end of the article
}

Our finding suggest the role of genetic polymorphism of Per2 in melatonin metabolism. Further analysis including digital mammography, antioxidative status and clock genes expression will contribute to the knowledge on the role of the shift work in breast cancer etiology.

\section{Acknowledgements}

This project is supported by a grant from the Polish-Norwegian Research Fund (PNRF 243-Al-1/07)

\section{Author details}

${ }^{1}$ Department of Toxicology, Nofer Institute of Occupational Medicine, Lodz, Poland. ${ }^{2}$ Department of Occupational and Environmental Epidemiology, Nofer Institute of Occupational Medicine, Lodz, Poland. ${ }^{3}$ National Institute of Occupational Health, Oslo, Norway.

Published: 24 September 2010

\section{doi:}

Cite this article as: Reszka et al:: Circadian gene variants and MT6s level in nurses under different work shifts - preliminary results. $B M C$ Proceedings 2010 4(Suppl 2):P54.
Submit your next manuscript to BioMed Central and take full advantage of:

- Convenient online submission

- Thorough peer review

- No space constraints or color figure charges

- Immediate publication on acceptance

- Inclusion in PubMed, CAS, Scopus and Google Scholar

- Research which is freely available for redistribution

Submit your manuscript at www.biomedcentral com/submit
C Biomed Central 